\title{
Geographic Influences in the Development of Texas
}

\section{Frederic William Simonds}

To cite this article: Frederic William Simonds (1912) Geographic Influences in the Development of Texas, Journal of Geography, 10:9, 277-284, DOI: $10.1080 / 00221341208985710$

To link to this article: http://dx.doi.org/10.1080/00221341208985710

曲 Published online: 20 May 2008.

Submit your article to this journal $₫$

Џ Article views: 3

Q View related articles ¿ 


\section{THE JOURNAL OF GFOGRAPHY}

VOLUME $\mathrm{X}$

MAY, 1912

NUMBER 9

GEOGRAPHIC INFLUENGES IN THE DEVELOPMENT OF TEXAS

By FREDERIC WILLIAM SIMONDS,

The University of Texas, Austin

PHYSIOGRAPHIC FEATURES

IN order to understand fully the geographic influences which have pre-

vailed in the development of Texas, it becomes necessary, first of all, briefly to treat of its salient physiographic features. The most westerly of

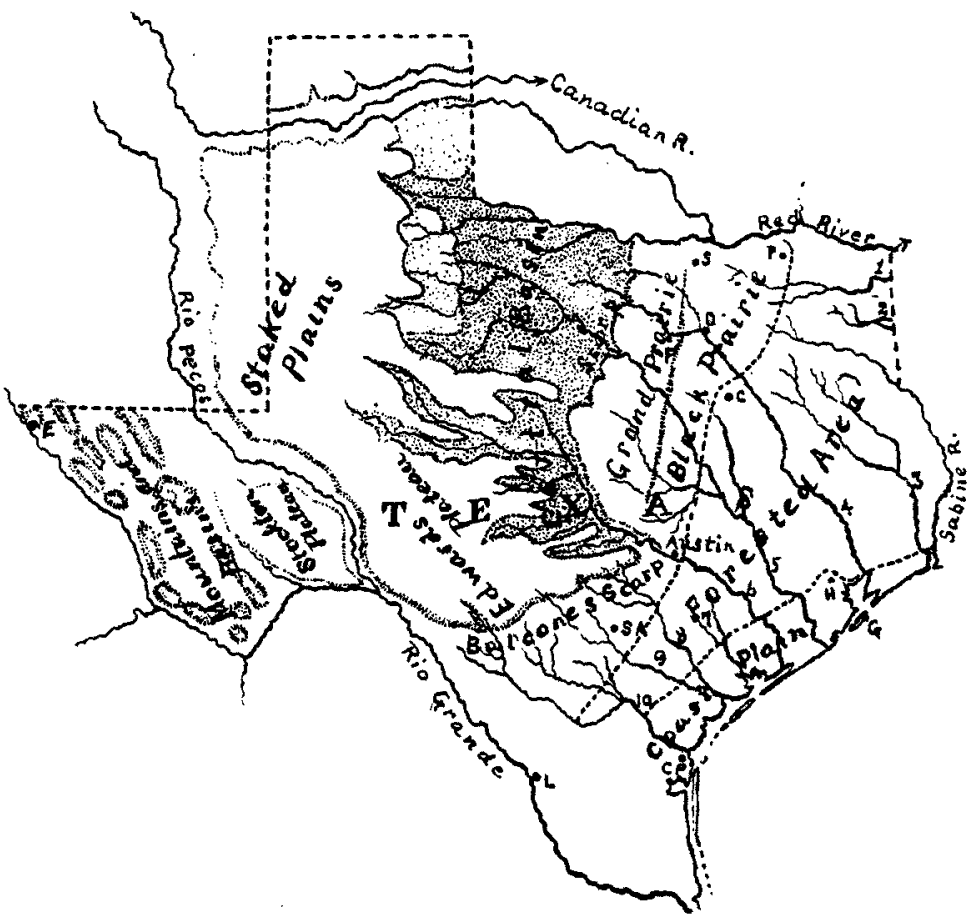

the Gulf states, it has a shore line approximately 375 miles in length, extending in a great crescent from the mouth of the Sabine to that of the Rio Grande. The seaboard land is low and is fortified with many long, narrow islands and peninsulas. In consequence of this the natural in- 
dentations of the land are more or less closed, being, as a rule, connected with the open water by comparatively narrow and, for the most part, shallow inlets.

Skirting the coast there is a young coastal plain of varying width, say thirty miles wide on the Sabine and a hundred on the Colorado River. Sparsely wooded, and with many open and grass-covered prairies, this region is often called the "Coast Prairie." Towards the southwest the effects of an ever-increasing aridity become more and more apparent.

The approximate boundaries of the forested area are shown in the figure. In this region the rolling prairies of the south are succeeded by the topography of a dissected plateau of mild relief (500-700 ft.). Here the forest growth has been, and still is, of much importance commercially. It includes the long-leaf, the short-leaf and the loblolly pines, widely used for building purposes, as well as numerous hard wood species, such as oak, ash, hickory, ete. The effects of aridity upon the timber begin to appear southwest of the Colorado River, and in the region of the Nueces River this area blends with the so-called "chaparrel country," which is characterized by clumps and thickets of thorn-bearing plants, such as the mesquite and acasias. As a matter of geologic interest it may be stated here that the Forested Area is underlain chiefly by rocks of the Eocene Tertiary.

Succeeding the Forested Area to the west are the Black and Grand Prairies, two well-marked regions, underlain by Cretaceous strata and widely known on account of the depth and fertility of their soils. On the south, southwest and west the Grand Prairie is bounded by an inward facing scarp overlooking an area generally known as the "Central Basin," extending from Austin to beyond the Red River in Oklahoma (see figure).

Stretching somewhat south of west, from Austin to the Rio Grande near Del Rio, there is an abrupt displacement, known as the Balcones Scarp, which separates the Edwards Plateau from an inward extension of the Coast Plain. This unique topographic feature exerts a marked effect upon the regetation as is at once apparent by a comparison of the floras of the upthrow and downthrow sides. The remainder of the State is included in the region of Plateaus and that of the Trans-Pecos Mountains and Basins. The Staked Plains are separated from the general plateau region east of the Rocky Mountains by the valley of the Canadian River. Their surface is very level, grass-covered, and marked here and there with a growth of Bear Grass and Yucca.

The Edwards Plateau, in its geological relations, is closely connected with the Grand Prairie to the east, and, although a plain when viewed as a whole, it has been trenched by deep-canyoned streams and its borders are much eroded. The third plateau area is comparatively small. It is known as the Stockton Plateau and is separated from the Edwards Platean by the Pecos River. The larger part of Trans-Pecos Texas is includ- 
ed in what has been termed the "Region of Mountains and Basins." Guadalupe Peak, just south of the Texas-New Mexico line, is the highest point in the State, having an altitude of 9500 feet. The basins of the Trans-Pecos country are plateau-like in elevation, but instead of having a relief resulting from degradation they usually present a surface covered with the erosion products of the surrounding heights.

\section{CLIMATE AND RAINFALL}

In a State embracing 265,780 square miles great variations must be expected in the amount of rainfall as well as in the other climatic conditions. In the east, there is a humid belt having an annual precipitation of from 50 to 60 inches. This includes a large part of the pine woods of the Forested Area. The adjoining belt on the west is rather broad, including the Black Prairie, a portion of the Grand Prairie, and a part of the Post Oak country to the south. Here the rainfall is from 40 to 50 inches. This is followed by a rather narrow belt, extending from the Red River to near the mouth of the Rio Grande, having a rainfall of 30 to 40 inches. Within this belt are included parts of the Grand Prairie and the Central Rasin, and that portion of the coast country between the Guadalupe River and the Rio Grande. This is succeeded by a broad belt with a diminishing rainfall, varying from 20 to 30 inches, which includes the larger part of the Central Basin and the eastern portions of the plateaus. Farther west there is a very scanty rainfall-from 20 down to 10 inches. The latter amount would represent the average fall at El Paso.

\section{RIVERS}

Several distinct types of river drainage are found in Texas: (1) The Canadian, a tributary of the Arkansas River, and the Pecos, a tributary of the Rio Grande, rise in the Rocky Mountain region of New Mexico, while the Rio Grande, likewise of Rocky Mountain origin, heads in southwestern Colorado.

(2) From the Edwards Plateau flow the Nueces, its tributary, the Frio, and the Guadalupe.

(3) Some of the best known Texas rivers, the Red, the Trinity and the Brazos, have worked their way seaward from the Central Basin through the successively younger formations of a rising continent.

(4) Flowing directly into the Gulf, or united to the older and more vigorous streams as tributaries, are the rivers originating on the older portions of the Gulf slope such as Sulphur Fork of Red River, the Sabine, the Neches, the Angelina, and certain tributaries of the Brazos and Trinity.

(5) Lustly there are the streams, constituting the immature drainage of the Coast Plain, but recently established and poorly defined. Of the rivers reaching the Gulf the majority empty into coastal indentations 
or bays, but the Brazos and Colorado have pushed gulfward a delta-like protrusion, as has also the Rio Grande, thus forming a delta shore line.

\section{IEISTORICAL RELATIONSFIPS}

The early history of Texas is mainly that of the rival claims of the Spanish and French. The former, soon after the discovery of America, had possessed themselves of Mexico, while the latter at a much later period had established themselves near the mouth of the Mississippi. Between them stretched a wilderness, unoccupied save by the Indian, destined to become later the largest and one of the most populous states of the Union.

The Spanish claimed Texas by virtue of their early royages; the French, by virtue of La Salle's unfortunate settlement. The latter, having descended the Mississippi, claimed in the name of the French king the lands through which it flowed. Returning to France he organized an expedition to take possession of the country. Midyear, 1684, with four ships he sailed for the mouth of the Mississippi. Entering the Gulf of Mexico, an unknown sea, the expedition which had already suffered the loss of one vessel by Spanish capture, sought vainly for the Mississippi entrance. Finally, nearing the land, it encountered the island reefs fringing the Coast Plain of Texas. Through an inlet, mistaken for a distributary of the great river, the ships endeavored to pass, a feat accomplished by two in safety while the third was wrecked. The haven thus reached is now known as Matagorda Bay, an arm of which, the present Lavaca Bay, afforded ample shelter. Having selected a suitable site a few miles above the mouth of Lavaca River, La Salle established Fort Saint Louis; though afterward destroyed by the Indians, this was the first European settlement in Texas.*

As already stated the harbors of Texas suited to the purposes of navigation are not numerous. In 1816 we find Galveston Island, now the seat of the State's greatest, and in many respects only seaport, occupied by a band of revolutionists, who had not failed to recognize the advantages of the sheltered arm of Galveston Bay. The short-lived settlement of the "Republicans" was soon followed by that of the so-called "Pirate of the Gulf," Jean La Fitte, who established here his headquarters. The present city of Galveston dates from 1837. By the construction of jetties and by dredging, deep water has been secured so that vessels of the largest size may receive and discharge their cargoes at the docks.

Second in importance is the combined port of Sabine Pass and Port Arthur on Sabine Lake. The products of the Texas-Louisiana forests had long been shipped in small vessels from Sabine Pass, but the building of a ship canal in Sabine Take and the development of Port Arthur, four-

*G. P. Garrison, Texas, A Contest of Civilizations, American Commonwealths, Chapter III. 
teen miles from the Gulf, is a recent achievement brought about largely by the enormous output of the Beaumont oil fields.

In 1821 stores for the first American colonists in Texas (Austin's colony) were shipped from New Orleans on the schooner "Lively" which effected a landing at the mouth of the Brazos River. Here the port of Velasco has been established and the building of jetties has given 16 feet of water on the river bar.

A breach in the chain of coastal islands, known as Aransas Pass, affords access to Corpus Christi, Rockport and the town of Aransas Pass. Point Isabel, near the mouth of the Rio Grande, is reached through an inlet-Brazos Santiago-south of Padre Island. Here the depth of water will accommodate only vessels of light draft. Formerly this pass afforded an entrance to the "Brownsville" or Lower Rio Grande country, but since the advent of railroads it is little used.

The crossing of the Texas wilderness in 1714 by the Frenchman, Saint Denis, who blazed the way of the "Old San Antonio Road," was an event of no little importance. Although his trip must be classed as a purely commercial enterprise, it opened to the world the country between the Sabine and the Rio Grande.

About this time a previous unsuccessful attempt on the part of the Spanish to establish missions was renewed. Ostensibly for the conversion of the Indian, the missions became the means of making good the Spanish claims to Texas. Some of the missions were established in the Forested Area; others in the Southwest. Of the former, practically nothing now remains; of the latter, the magnificent ruins on the San Antonio River tell of a wonderful work. Here conditions were favorable to the establishment of an industrial community. From the river and numerous springs an abundance of water was obtained for irrigation and in the mild though somewhat dry climate, stock of all kinds flourished. It was here that the Indian workmen, taught by the patient Spanish Fathers and their faithful attendants, developed much skill, not only as artisans but as farmers and stockmen as well. About one of these missions, that of San Antonio de Valero, better known as the Alamo (established in 1718), there has since developed, under the guidance of the Anglo-American, the largest city of the State, San Antonio. (Population, 96,614.)

Were this a history of Texas rather than a brief account of the physiographic influences bearing upon its development, many important details, here omitted, would be given.

Coming now to the advent of the Austins, father and son: It must be understood that, notwithstanding its great distance from the AngloAmerican settlements, Texas had already attracted much attention. In 1819 Moses Austin conceived the idea of establishing a colony; the following year he journeyed to San Antonio and with difficulty gained permis- 
sion to settle 300 families. The good news had scarcely been received when the elder Austin died leaving the matter of his Texas settlement in the hands of his son, Stephen F. Austin, who loyally carried out his father's wishes. Arriving at San Antonio in August, 1821, he found that Mexico had seceded from the mother country.

Austin now planned for his settlement. With a party of colonists, he arrived in the valley of the lower Brazos during the closing days of 1821. In 1823 San Felipe de Austin, on the Brazos, became the seat of government for the colony and so remained until the establishment of the Republic.

In 1825 grants of land were made to Martin de Leon, a Mexican, and to Green De Witt, an American, and both established colonies. Notwithstanding the material and political hardships of the settlers-defending their homes from savage bands on the one hand, and resisting the oppressive laws of a remote authority on the other-the net result of ten years' growth is summed up in the following sentence from a well known Texas History: "In 1820 there were not more than 4000 civilized inhabitants in Texas, while in 1830 the State boasted of 20,000 Americans alone.*

Passing the era of the Texas Revolution with its desperate struggles and unparalleled acts of heroism, passing likewise the era of the Republic, let us glance at Texas as it appeared about the time of its admission to the Union in 1845. Before me is a map by Dr. Ferd. Roemer, the first geological map of the State published. It accompanies his work on "Texas" printed at Bonn in 1849. On it are marked the old lines of travel, the ferries on the Sabine, and the older Texas towns, of which some have entirely disappeared from present day maps, others have dwindled to obscurity, and still others have become large and prosperous cities. All of the larger streams, from the Sabine to the Nueces, have their settlements. Already roads radiate in all directions from the hamlet on Buffalo Bayou-the future city of Houston-prophetic of the greatest railroad center in the State. Far up the Trinity, on the very frontier, reached by a single line of travel, Dallas is accorded a place-the germ of the North Texas metropolis, while Fort Worth is yet to be. Austin, the present capital of the State, on the north bank of the Colorado at the foot of the Balcones Scarp, occupied at this time an isolated position for the main thoroughfare, the Old San Antonio or Presidio Road crossing the river lower down at Bastrop. Corpus Christi is the most southerly town on the coast, while between the nueces and the Rio Grande no settlements appear excepting Laredo, and that is Mexican rather than Texan.

\section{RAILROADS}

The late Professor Garrison has said that one standard by which the progress of a people may be measured with substantially fair results is

*Pennybacker's New History of Texas. 
their means of intercommunication. He had reference to railroads. It is needless to say that while some physiographic features are of the greatest importance in railroad building, others offer insuperable difficulties. In Texas the first railroad was built on the low coastal plain between Harrisburg, a few miles from Houston, and the Colorado River opposite Columbus. Today it forms a part of the transcontinental "Sunset Route" operated by the Southern Pacific Company.

It may be well to consider briefly why a transcontinental line should cross the State of Texas, especially the southern part. Railroads are not only expensive to build but expensive to operate. Of competing lines the advantage is with that having the lowest grade. Between New Orleans and Ios Angeles, or San Francisco, the highest point encountered on the "Sunset Route," 5,082 feet, is at Paisano, Presidio County, Texas. In short, this line avoids the high grades of the more northern roads by a well selected southern course.

An examination of a railroad map of the State is most interesting. North of the 28th parallel and east of the 99th meridian the conditions have been most favorable for railroad building. The larger part of this area is included in the Great Coastal Slope, a region embracing the Coast Plain, the Forested Area, and the Black and Grand Prairies, geologically distinguished by the southeastern dip of the underlying strata. In the process of their development some of the railroads pushed to the north for Saint Louis and Kansas City, while others pushed to the south and southeast for the port of Galveston. Still others headed southwest seeking the Rio Grande border for Mexican or transcontinental connections. Finally the Great Plains were crossed by roads affording Colorado and New Mexico, either directly or by affiliated lines, the advantage of a deep-water port on the Gulf.

\section{CITIES}

The chief railroad centers of the State, ganglia on the map, are Houston, on the inner border of the Coast Plain, and Dallas and Fort Worth on the Black and the Grand Prairies respectively.

Through Buffalo Bayou, Houston, though fifty miles northwest of Galveston, has water connection with the. Gulf and, if present plans are consummated, this water-way will soon be transformed into a ship canal, thus making the city a seaport. Already seventeen railroads center here, of which several extend to Galveston. Houston is one of the great cotton markets of the world and the seat of an important trade in lumber, rice and sugar. (Population, 78,800.)

Dallas dates from 1841. It is the commercial center of a large region, embracing parts of Texas and Oklahoma, devoted chiefly to agriculture. The adjacent prairies are noted for their fertility, producing not only cotton but large crops of wheat and corn. To Dallas has been 
awarded the distinction of being the largest distributing point for agricultural implements in the Southwest. (Population, 92,104.)

Fort Worth, thirty miles west of Dallas, originated in a settlement about a military post established in 1849 . For years it has been the seat of trade for the "cattle country," including not only the Panhandle but the entire plateau region between the Red River and the Pecos. Its stockyards and packing interests are the most extensive in the southwest, and considering its proximity to Dallas, its growth in the past few years has been remarkable. (Population, 73,312.)

In Texas Cotton is King. The raising of cotton in the Old South was the leading industry of the ante-bellum days. The large plantations with slave labor produced enormous crops. As the land was exhausted new areas were brought under cultivation in consequence of which the growth of cotton was extended towards the south and southwest, spreading gradually into East Texas. During the War the Old South was continually harassed by the contending armies to the great detriment of its industries, especially its agriculture. In Texas, at this time, the rigor of conflict was not so severe and cotton crops were successfully made. When the South finally emerged from the desolation of the Civil War the production of cotton in Texas had become a deeply rooted industry. The areas under cultivation continued to broaden until the rich lands of the Black and Grand Prairies became the largest producers in the State. And still the industry spread until now cotton is raised even in some of the Panhandle counties-a region heretofore considered too dry for profitable cotton growing. Thus it has come to pass that Texas is today the leading cotton producing State of the Union, its largest crop, that of 1906, exceeding four million bales.

\section{GEOGRAPHY OF THE UNITED STATES IN THE HIGH SCHOOL}

BY HARLEY P. CHANDLER,

Principia School, St. Louis, Mo.

$\mathrm{T}^{\mathrm{B}}$

HE question, What is worth while? loses none of its force by reason of its old age. It is a pertinent inquiry which every school man should keep before himself at all times. When a subject bids for admission to the curriculum it is legitimate and right to demand proof that it is worth while. In order to be worth while, it must contribute something vital to the education of citizens-to-be. This contribution may be practical, enabling one better to satisfy his material needs; it may be cultural, giving him breadth of view and greater capacity to enjoy life; or it may be a training in methods of thinking and working, which will enable him better to secure the practical and cultural objects.

Geography has for centuries been acknowledged to contribute sufficiently to practical and cultural needs to be entitled to an important place 